\title{
PUEBLA: HISTORICIDADE E OPÇÕES TEOLÓGICAS
}

\author{
Puebla: Historicity and Theological Options
}

João Décio Passos *

RESUMO: A Conferência de Puebla foi realizada como epicentro de um processo histórico-eclesial demarcado por lutas hermenêuticas. O significado da Conferência de Medellín, porém antes, o significado do próprio Vaticano II colocava-se no centro dessa disputa. Dois modelos teológicos distintos confrontaram-se nessa interpretação: um primeiro de matriz clássica e um segundo de matriz moderna. Não obstante a legitimidade eclesiástica do primeiro modelo, o segundo triunfou como aquele capaz de interpretar o momento histórico e responder aos seus desafios. Os conceitos de consciência histórica e de historicidade fornecem o arcabouço sobre o qual repousa essa teologia que na América Latina foi formulada com a nomenclatura "teologia da libertação".

PALAVRAS-CHAVE: América Latina. Episcopado. Historicidade. Igreja. Puebla.

ABSTRACT: The Puebla Conference was held as the epicenter of a historical and ecclesial process marked by hermeneutic struggles. The significance of the Medellin Conference, but before, the significance of Vatican II itself was at the center of this dispute. Two distinct theological models were confronted in this interpretation: the classical matrix and the modern matrix. Notwithstanding the ecclesiastical legitimacy of the first model, the latter triumphed as one capable of interpreting the historical moment and responding to its challenges. The concepts of historical consciousness and historicity provide the framework upon which this theology rests, which in Latin America was formulated under the nomenclature "liberation theology".

KEYWORDS: Latin America. Episcopacy. Historicity. Church. Puebla.

\footnotetext{
*Pontifícia Universidade Católica de São Paulo, São Paulo, Brasil.
} 


\section{Introdução}

III Conferência configurou um momento estratégico de correção das
rotas do aggiornamento desencadeado pelo Vaticano II, aprofundado e amplificado na práxis eclesial latino-americana. Quinze anos depois do Concílio da renovação era tempo de imprimir um rumo na Igreja que fosse capaz de corrigir os exageros e as falsas interpretações sobre as decisões daquele evento normativo da Igreja universal. A América Latina e, de modo institucional, a II Conferência do Episcopado realizada em Medellín em 1968, representava um marco emblemático por haver legitimado práticas pastorais e reflexões teológicas pouco afeitas à tradição católica e, em boa medida, à reta doutrina. Era tempo de rever os rumos da Igreja do continente. Essa era a perspectiva defendida por uma frente de prelados, contando com a retaguarda da própria Cúria romana e, já em boa medida, do novo papa, João Paulo II.

De fato, a III Conferência será encampada como evento estratégico para duas tendências: para aquela que pretendia fazer uma revisão dos rumos da Igreja a partir de referências seguras de doutrina e de práticas eclesiais e para aquela que entendia ser necessário preservar e avançar nas intuições e orientações emanadas de Medellín.

A luta entre uma oficialidade com sua hermenêutica revisora de Medellín (e do Vaticano II) e uma frente eclesial local determinada a preservar Medellín com sua hermenêutica de raiz conciliar vai configurar o antes, o durante e o pós Conferência de Puebla. A assembleia instala-se sob essa tensão que despertava interesse das mídias e preocupação de prelados, religiosos, agentes leigos e teólogos locais. Os representantes da tendência revisora contavam com uma legitimidade tradicional ou uma "identidade legitimadora" que advinha dos setores dirigentes da própria Igreja. Munidos com uma teologia pretensamente oficial e ortodoxa afirmavam desvios flagrantes nas Igrejas do continente e a necessidade de correções imediatas. Os sujeitos eclesiais renovadores contavam com outra legitimidade, aquela denominada "identidade de projeto" (CASTELLS, 2001, p. 25-27) que tem como mérito e fraqueza precisamente a proposição do novo como saída legítima para as dificuldades emergentes. Embora no âmbito do ethos católico a legitimidade tradicional vença de saída toda situação de embate prático ou teórico, em nome da verdade preservada em sua integridade pelas autoridades oficiais, em Puebla essa luta, semelhante ao que ocorreu no Vaticano II, não poderá dispensar a referência da historicidade para pensar a missão da Igreja naquele momento dramático dos povos do continente e, por conseguinte, a própria Igreja e as demais formulações de fé. $O$ projeto novo carrega como mérito precisamente aquilo que falta ao tradicional: a proposição de saídas interpretativas e práticas para os desafios emergentes. Por essa razão, ele tende a tornar-se hegemônico, 
na medida em que os debates se mantêm na perspectiva da fidelidade à realidade histórica. $\mathrm{O}$ vínculo com a realidade histórica exige por lógica e coerência novas proposições capazes de oferecer compreensões e saídas aos problemas detectados. As referências fixadas no passado não conseguem por si mesmas decodificar o presente e têm que encontrar os modos de articular-se com as interpretações emergentes para que possam cumprir sua função hermenêutica.

Desse quadro concreto emerge a hipótese central dessa reflexão: o documento final de Puebla (DP) expressa uma consciência histórica que triunfa da cosmovisão essencialista que rege uma matriz teológica clássica, um método dedutivo decorrente e um modo de compreender o exercício do magistério da Igreja que pretendeu ser a teologia legítima da III Conferência. A sensibilidade e percepção da realidade histórica possibilitaram a leitura teológica do presente e a leitura da tradição a partir do presente. Essa circularidade hermenêutica é constitutiva do pensamento teológico de Puebla, não obstante suas reproduções do esquema teológico clássico.

\section{Colocação do problema}

A III Conferência do Episcopado Latino-americano ocorre em um contexto e marco eclesiais definidos por uma "luta pelo sentido" do Vaticano II, conforme bem formulou o teólogo Massimo Faggioli (2013). A tendência revisora do significado do processo de aggiornamento intencionado pelo Papa João XXIII, que se mostrara minoritária no âmbito da assembleia conciliar, ganhou fôlego e adeptos e, por conseguinte, legitimidade e força política na década seguinte ao grande evento. Tratava-se de uma tendência que aglutinava adeptos de posições mais ou menos radicais, porem com um acordo, ao que parece fundamental: o aggiornamento conciliar havia conduzido a Igreja a uma crise; essa crise advinha de uma compreensão equivocada do Vaticano II; era necessário corrigir os erros de compreensão sobre os ensinamentos conciliares; para tanto várias estratégias deveriam ser assumidas na esfera da doutrina e da práxis eclesiais. Se, na assembleia conciliar, a minoria que temia as renovações tinha nome e endereço e se tornara sempre mais residual em suas frentes de batalha, agora tratava-se de uma tendência com algumas características sócio-políticas peculiares: a) aglutinação de vários sujeitos eclesiais em torno da causa revisora; b) número crescente de adeptos de perfil eclesial tradicional; c) composição difusa que contava com sujeitos espalhados pelo conjunto do corpo eclesial; d) frente disposta a rever os processos de renovação a partir de parâmetros anteriores (Vaticano I), porém no marco da comunhão eclesial católica; e) frente que se legitima sempre mais, uma vez capitaneada pelos setores dirigentes da Cúria romana e pelo Papa, após a eleição de Karol Wojtila; 
f) frente que reivindica para si a pureza da tradição e da doutrina como parâmetro hermenêutico da revisão do aggiornamento efetivado na América Latina desde Medellín.

A III Conferência instala-se nesse quadro histórico-eclesial de luta estratégica pela revisão do sentido do Vaticano II (LIBANIO, 1984; ZEPEDA, 2018). A Conferência de Medellín havia sido emblemática nos termos da renovação conciliar. Em nome desse projeto os bispos da América Latina aprofundavam e alargavam as intuições e orientações conciliares em termos eclesiais (no exercício da colegialidade episcopal e na concretização da Igreja povo de Deus) e pastorais (na inserção na história e na solidariedade para com os pobres), em termos teológicos (teologia articulada na volta às fontes e na acolhida da realidade histórica) e metodológicos (o método ver-julgar-agir) e em termos sociais e políticos (a crítica das opressões e injustiças e a defesa dos direitos humanos). Os impactos sociais e políticos de Medellín no continente tornaram-se problemáticos para a instituição eclesiástica, aliada histórica das elites locais e imbricada em relações diplomáticas com os estados nacionais. Mas, na esfera doutrinal, a velha institucionalidade eclesial sentia-se igualmente desvestida da segurança da verdade e desfigurada na identidade que a distinguia do mundo. Ademais, os avanços da reflexão teológica contribuíam com essas instabilidades e deveriam ser corrigidas com urgências. No caso do continente, os riscos de uma teologia articulada com as esquerdas e com os métodos da análise marxista mostravam-se como caminhos equivocados. Dez anos depois das experiências ambíguas deflagradas por Medellín era a hora precisa de uma revisão eficiente a ser capitaneada pelos setores dirigentes da Igreja, por aqueles que haviam chegado à direção do CELAM, pelos delegados nomeados por Roma e pela tendência conservadora do episcopado ali presente. O Documento de Consulta elaborado como preparação da Conferência tinha precisamente esse objetivo de rever e corrigir a caminhada da Igreja de Medellín. Muitos temiam uma revisão que rompesse com as orientações de Medellín, sob a coordenação direta do Secretário do CELAM e da própria Conferência (CASALDÁLIGA, 1978, p. 585-586).

A III Conferência instalou-se com esse objetivo revisor claro e explícito. A suspeita de um controle direto da parte do secretário López Trujillo confirmou-se quando veio a público uma Carta escrita pelo mesmo a um prelado do Brasil prevenindo-o para o embate ideológico da assembleia. ${ }^{1}$ Na observação de Dussel "sem nenhum lugar de dúvida, a secretaria geral do CELAM estabeleceu um plano, contava com seus peritos, e esperava poder chegar a bom termo suas finalidades" (1981, p. 46). Um alinhamento revisor de Medellín havia, de fato, sido planejado e contava com adeptos importantes. No discurso inaugural o Papa João Paulo II falara claramen-

\footnotetext{
${ }^{1}$ Carta publicada pelo jornal mexicano Uno más uno de 1.ํ de Fevereiro de 1979 (DUSSEL, 1983, p. 592). A interpretação de López Trujillo sobre o sentido de Puebla foi explicitada posteriormente na obra Opções e interpretações à luz de Puebla. São Paulo: Loyola, 1982.
} 
te na necessidade de revisão de rumos. A III Conferência deveria tomar como ponto de partida as conclusões de Medellín "com tudo o que tem de positivo, mas sem ignorar as incorretas interpretações por vezes feitas e que exigem sereno discernimento, oportuna crítica e claras tomadas de posição" (CELAM, 1982, p. 14).

Se, em Medellín, a teologia elaborada no continente fornecera um eixo teológico fundamental para as reflexões, o que permite falar "em teologia do documento final" de uma forma singular, agora em Puebla predomina a diversidade, senão a ambiguidade teórica (teológica), ainda que sob uma unidade dogmática dos conteúdos e uma unidade formal do texto. A luta pela revisão de Medellín produziu essa fragmentação teológica no texto final, porém deixando ressaltar em primeiro plano os apelos da história e as opões pastorais. A opção pastoral significava necessariamente um posicionamento perante o contexto histórico. E para essa atividade hermenêutica a faca de melhor corte era, inevitavelmente, a teologia mais temida de alguns setores eclesiais vigilantes da ortodoxia: a teologia da libertação.

A luta pelo sentido do Vaticano II traduzia-se naquele momento em luta pelo sentido de Medellín. E, assim como na assembleia conciliar, havia uma luta hermenêutica (sentido da fé e da história) regida por diferentes teologias, porém polarizada na questão disputada da teologia da libertação (COMBLIN, 1981, p. 100-102). De um modo geral e, até mesmo tipológico, podem-se detectar duas frentes teológicas em disputa, regidas por duas matrizes metodologicamente distintas: uma teologia clássica de raiz agostiniana/escolástica e uma teologia que pode ser definida de maneira genérica como teologia histórica, construída durante o século XX em variados modelos (GIBELLINI, 1998). A primeira opera a partir do esquema maior criação-queda-redenção, traduzido no esquema médio, Jesus Cristo-Igreja-sacramento que se traduz, por sua vez, no esquema operacional menor Papa-verdade-fidelidade. A teologia tradicional católica pensa a realidade presente a partir desse pressuposto. A segunda, embora não negue a primeira, opera de modo dialético e indutivo: história-revelação-discernimento-ação. Nessa percepção e método recoloca as fontes e a tradição em sintonia com o momento presente. A primeira conta com um edifício bem elaborado, dogmaticamente instituído, consolidado no imaginário católico e com modos de operação fixos e claros na dinâmica regular da vida eclesial/eclesiástica. A segunda exige elaboração que confronta a fé com a história, bebe dos estudos exegéticos modernos, dialoga com as ciências e com a realidade presente. Tanto quando no Vaticano $\mathrm{II}^{2}$ essas

\footnotetext{
${ }^{2}$ Massimo Faggioli tipifica essas tendências no âmbito do Concílio Vaticano II como Agostinianos e Tomistas (2013, p. 102-131). Elas catalisam no nosso entender duas perspectivas teológicas e metodológicas distintas, a essencialista e a histórica. A era do Vaticano II demarca a emergência da segunda e a luta por hegemonia em relação à primeira no conjunto das percepções e práxis eclesiais.
} 
duas tendências estão presentes na III Conferência e se mostram nítidas no documento final.

O DP apresenta, de fato, uma teologia clássica em sua segunda parte de cunho doutrinal, deixando claro que predominou como hegemônico esse modo de formular a fé, ali evidentemente identificado com a própria verdade da fé. Contudo, o exame atento do conjunto e de passagens localizadas do mesmo documento surpreende a presença ativa da segunda matriz, evidentemente ancorada nas reflexões da teologia da libertação que palpitavam no antes e no entorno da Conferência como paradigma vivo disponível a interpreta o contexto histórico e a Igreja naquele momento urgente.

Numa palavra, a teologia do DP é de um modo geral - por certo, oficial - regida pela matriz clássica, ao menos em termos de fundamentação doutrinal e de uma suposta intencionalidade fundamental do documento final. A parte II - o julgar - expressa com clareza esse posicionamento. Contudo, trata-se de um esquema tradicional que incorpora elementos renovadores, evidentemente do Vaticano II e da própria teologia latino-americana, teologia que é a principal suspeita de desvios e que deve ser assumida, purificada e elevada pela ortodoxia ali vigilante e operante. A Conferência de Puebla foi, de fato, um momento dialético no pensamento e na práxis da Igreja naquele contexto de final da década de setenta. A presença desses modelos teológicos revela, ao mesmo tempo, a força e o limite da matriz teológica clássica que é utilizada como referência legítima e como doutrina segura pelos que pretendem corrigir os rumos da teologia subjacente a Medellín e operante na Igreja latino-americana. Mas, o processo histórico mostra o limite dos esquemas teológicos clássicos para se pensar a realidade histórica com seus dramas humanos concretos, com seus clamores e urgências sociais e pastorais. Perante os problemas históricos sinceramente acolhidos como clamor do povo de Deus, fórmulas teológicas não são, de fato, suficientes para oferecer critérios de discernimento e de ação.

Com efeito, perseguindo a hipótese de uma analogia entre Vaticano II e Puebla, pode-se afirmar que não obstante as constantes teológicas clássicas, a sensibilidade para com a história real faz triunfar no subtexto e, de modo difuso no texto, um modelo teológico que articula fé e realidade. É precisamente esse que vai conectando as passagens teológicas mais clássicas e de lógica dedutiva na historicidade da salvação, na qual convergem a percepção da revelação como processo histórico-salvífico que culmina em Jesus de Nazaré e o processo histórico presente com suas interrogações e urgências. No fundo pode ser encontrada como fonte e base desse modelo a consciência histórica gestada na longa temporalidade moderna, consciência que brota da percepção da relevância do processo histórico na constituição das ideias, da afirmação do protagonismo dos sujeitos na 
constituição dos poderes e das interpretações e do imperativo do exame histórico-crítico dos modelos teóricos. Os dois tópicos seguintes visam, respectivamente, identificar as raízes histórica e eclesial desse modelo e sua presença no DP.

\section{Consciência histórica e método do Vaticano II}

A luta hermenêutico-teológica presente no Concílio descansa, portanto, sobre o confronto entre as visões essencialista e histórica da realidade, com seus respectivos métodos, fontes e conteúdos doutrinais. O Vaticano II, como expôs magistralmente Christoph Theobald, representou um momento preciso de recepção teológica da racionalidade histórica, já desde as teologias que antecederam o evento ainda na primeira metade do século $\mathrm{XX}$ (2015, p. 122-202). Essa racionalidade assimilada teologicamente marcará presença na III Conferência e a sustentará como argumento de fundo que salva o DP de uma hegemonia conservadora. Se a teologia explicitada na parte doutrinal do DP é nitidamente de cunho tradicional-conservador, no entanto uma postura de sensibilidade para com a história real permite ver outra interpretação das verdades sobre Jesus Cristo, o homem e a Igreja em pontos localizados do documento e, por certo, em uma opção de fundo que foi minimamente possibilitada pelo método ver-julgar-agir. Contudo, a teologia da libertação evitada e mal-vinda à assembleia oferecia de modo vigoroso os elementos dessa percepção e formulação e exercerá de modo indireto a sorrateiro esse serviço de ancoragem das orientações da III Conferência na história presente. Nesse tópico será feito um recuo histórico e conceitual visando resgatar o processo de emergência da consciência histórica na Igreja católica nos tempos modernos, tendo como ponto de chegada e de partida o Concílio Vaticano II. Uma passagem gradativa de uma consciência metafísica de raiz platônica, centrada nas essências estáveis, para uma consciência do lugar central da história na compreensão do ser humano e de Deus demarca essa temporalidade de mudanças na Igreja.

\subsection{A emergência da consciência histórica}

A percepção da determinação histórica sobre as concepções e dessas sobre a história constitui o centro dinâmico da consciência histórica e reivindica para a histórica um lugar central para a compressão de todas as produções humanas (ABAGNANO, 2007, p. 227). A consciência histórica, como se sabe, emerge na sua expressão acabada no bojo da chamada modernidade e recebe formulação no âmbito da filosofia das luzes (CASSIRER, 1992, p. 267-313). Ainda que se deva examinar no fundo dessa postura moderna a concepção bíblica de ser humano inserido na história como 
criatura, lançado no jogo liberdade-responsabilidade e ancorado em uma perspectiva de futuro aberto e por se construir (VAZ, 2001, p. 189217), o fato é que essa postura firma-se gradativamente como conceito e como práxis a partir da Europa que se moderniza; ela vai demolindo e reestruturando as visões e as práticas com grandes e progressivos deslocamentos que rompem com a estabilidade cósmica antiga, com a unidade política, cultural e religiosa, com a cosmovisão hierárquica estruturante da cosmologia, da escatologia, da Igreja, da sociedade e da política, com a mentalidade essencialista que define as coisas, a partir de sua identidade estável e imutável, com o método lógico dedutivo, decorrente dessa visão que dinamiza as interpretações teóricas da realidade. A tradição católica, com seu rígido sistema teórico escolástico e com sua estrutura hierárquica, foi, de fato, a trincheira de frente desse processo demolidor e renovador que foi configurando-se como nova ordem, de forma lenta e definitiva. A experiência da historicidade, ou seja, de que os sujeitos humanos são os protagonistas capazes de desconstruir e reconstruir as instituições, as interpretações, os conhecimentos e os valores, consolida-se como consciência histórica: de que o processo histórico é o constitutivo da realidade econômica, social, política, cultural e religiosa. O homem e a sociedade que gradativamente emergiram desse processo pensam a agem como seres históricos, rompendo com as posturas estáveis que definiam o tempo e o espaço, sustentavam as ideias e as práticas e explicavam a natureza e a sociedade (VAZ, 2001, p. 165-218).

\subsection{Impactos e recepção da consciência histórica na Igreja}

Ainda que a Igreja tenha reafirmado sua tradição e construído estratégias de resistência que afirmavam o pré-moderno como parâmetro teórico e prático para vida eclesial e social, gradativamente vai recebendo os impactos da modernização e, por conseguinte, da centralidade hermenêutica da história na relação com as fontes, com as tradições teóricas e com as relações com a sociedade e, de modo direto, com os Estados modernos. As estratégias antimodernas afirmadas e desencadeadas desde Pio IX consolidaram sobremaneira um sistema eclesial e eclesiástico centralizado em uma concepção de verdade, de Igreja e de sociedade unitária, hierárquica, fixa e estável que expurgava todas as tentativas de recepção do pensamento moderno. Contudo, o processo em marcha de afirmação da consciência histórica vazava para dentro do sistema eclesial, a partir de baixo e a partir das bordas, mostrando seus impactos crescentes no laicato e na teologia. $\mathrm{Na}$ verdade, o mundo protestante avançara desde a reforma nessa direção e deixava seu legado, sobretudo, na colocação da circularidade entre sujeito fiel e escritura. Essa relação expunha o texto bíblico para além da interpretação oficial, verdadeira e única do magistério como mensagem a ser discernida e vivenciada pelas comunidades e por cada indivíduo. É sobre esse pressuposto de 
autonomia interpretativa que o método histórico crítico encontrou seu solo fecundo e original na tradição protestante. A história era assimilada como critério de discernimento do texto em si e na sua relação com os diversos contextos históricos

$\mathrm{Na}$ parte católica, no tocante à teologia, novas interpretações vão sendo construídas e podem ser visualizadas esquematicamente em duas fases:

\section{1ª: A Igreja interpreta/acolhe a história}

Os católicos sociais franceses que acolhem os valores da república e do pensamento moderno e encaram de frente os problemas sociais decorrentes da industrialização (ÁVILA, 1972), teólogos dão os primeiros passos na assimilação dos métodos históricos nos estudos bíblicos e o tomismo renasce como chave de leitura dos novos tempos. A hierarquia avança a passos lentos, mas decisivos, no pontificado de Leão XIII, sobretudo com suas Encíclicas sobre os estudos de Tomás de Aquino (Aeterni patris, 1879) e com a sensibilidade aos problemas modernos (Rerum novarum, 1891). A Igreja não escapava da necessidade de interpretar a história. Abre-se uma circularidade hermenêutica entre tradição católica e realidade histórica que crescerá, desde então, em amplitude e profundidade. $\mathrm{Na}$ outra ponta, o laicato organiza-se como sujeito eclesial e assume o protagonismo da fé por meio da grande frente da ação católica que se espalha pelo mundo (ALMEIDA, 2015b, p. 2-5). Assim nascem e avançam a doutrina social da Igreja, as teologias ligadas à história e os métodos pastorais que vão sendo utilizados pelos sujeitos eclesiais no decorrer do século XX.

\section{2ª: A história interpreta a Igreja}

Os métodos científicos modernos elaborados pelas ciências humanas na segunda metade do século XIX e, de forma decisiva, na primeira metade do século XX submetem todos os produtos culturais ao exame crítico, incluindo aqueles relacionados às religiões e, evidentemente, ao cristianismo. As religiões são produtos históricos como as demais linguagens e instituições culturais. A ressonância católica desses métodos torna-se inevitável e conhece as primeiras formulações ainda no século XVII com o oratoriano Richard Simon (1638-1712), embora nem sempre bem-vindas e, até mesmo condenadas como modernismo (VILANOVA, 1989, p. 806-808). O método histórico-crítico ocupava o lugar central nessa luta epistemológica. As teologias modernas entram em cena com novas percepções sobre a realidade imanente concretizada nos tempos modernos: autonomia da natureza e da história, autonomia humana e autonomia do pensamento. Nesse movimento, a Igreja é reinterpretada como povo de Deus, como comunidade de fé em marcha na história. Em posição semelhante às citadas Encíclicas de Leão XIII, a Encíclica Divino Afflante Spiritu (1943) de Pio XII cede às 
evidências científicas do método histórico-crítico. A história é assimilada como critério hermenêutico de compreensão do texto e, por conseguinte, de compreensão da própria revelação e da tradição da Igreja.

\subsection{A consciência histórica constitutiva do método e do pensamento conciliar}

O evento conciliar pode ser localizado como o epicentro da recepção da consciência histórica por parte do pensamento e da práxis católica e como ponto de chegada que recolhe, seleciona e formula essa postura fundamental e ponto de partida que remete para o período de aplicação das orientações conciliares. Diferentemente de outros Concílios construídos em um esquema jurídico unificador e uniformizador, o Vaticano II entrega ao conjunto da Igreja um processo a ser desencadeado desde então nos quadrantes do planeta, em sintonia com as Igrejas locais e com cada realidade. O Concílio entende-se e, por conseguinte, aplica-se mais como processo metodológico do que como decreto, mais como espírito do que como letra, mais como vivência eclesial sempre renovada do que como modelo eclesial uniforme e prefixado.

A ideia do novo Concílio, de paternidade exclusiva de João XXIII, é anunciada, desenvolvida e instituída, precisamente como expressão da consciência histórica que se constrói sempre e na raiz como esforço de relacionar passado e presente; circularidade que, no caso da tradição cristã, exige sempre uma leitura mútua ente conteúdos da fé e realidade presente, o que resgata na verdade o essencial da própria noção de tradição como transmissão. Desde o anúncio do novo Concílio, em 25 de janeiro de 1959, o Papa pôs-se a explicar progressivamente que se tratava de um Concílio não para definir doutrinas ou condenar erros, mas para fazer um aggiornamento da Igreja (ALMEIDA, 2015a, p. 8-9). Esse propósito carregava, de fato, o germe de uma dialética mútua entre passado e presente que exigirá uma verdadeira conversão metodológica dos padres conciliares, sabendo da unânime perspectiva católica marcada pelo essencialismo platônico, pelo exclusivismo doutrinal católico e pela ideia de autoridade doutrinal centralizada no magistério papal.

Fazer o aggiornamento da Igreja era um desafio do qual João XXIII tinha ciência. As explicações por ele dadas a cada audiência e discurso que desde então pronuncia para diferentes públicos revela sua pedagogia de deixar claro que se tratava de um novo Concílio (não como continuidade do Vaticano I) com um novo objetivo e um novo método. Como confrontar crítica e criativamente a Igreja com os tempos atuais, tendo sob os ombros da instituição milenar uma concepção autocentrada de verdade - eterna, universal e fixa - que negava como falsa a racionalidade moderna como um todo. Nessa empreitada, o Papa assume o comando na formulação do conceito e dos objetivos do novo Concílio, enquanto a Cúria romana 
encaminha ex officio os textos preparatórios com as 10 Comissões constituídas para essa missão. João XXIII dirige o processo estrategicamente, ao que parece, sabendo da divergência de concepção que estava em curso. Se, oficialmente, a Cúria, sob o comando do Cardeal Alfredo Ottaviani construía os estudos reproduzindo uma concepção estável de doutrina, tradição e Igreja, um autocentramento em oposição ao mundo eivado de erros, os trabalhos contam também com um novo dado: a instituição de um novo sujeito conciliar, o Secretariado para a união dos cristãos. E não se tratava somente de um órgão destinado a contribuir com o diálogo com as religiões, mas de uma nova perspectiva teológica e metodológica que irá, efetivamente, colocar o Concílio na rota do aggiornamento: no diálogo sempre mais claro e coerente entre as fontes e o presente. Para tanto a figura do eminente exegeta Agostinho Bea, versado no método histórico-crítico e no diálogo com o judaísmo, apresentou-se como um verdadeiro artífice do aggiornamento; deu voz, conteúdo e método para a intuição lançada pelo Papa e assegurou um novo modo de pensar a fé em sintonia com as realidades presentes.

Com efeito, em termos de consolidação de um método proposto ao novo Concílio, o Discurso inaugural escrito e pronunciado por João XXIII revela o ápice dessa compreensão por parte do pontífice. Ali insiste na natureza distinta do Concílio, realizado não para condenar, mas para acolher os novos tempos com misericórdia, vocacionado a acolher as contribuições positivas da mentalidade e dos métodos modernos e, de modo magistral, formula o critério básico de trabalho:

Uma coisa é a substância do "depositum fidei », isto é, as verdades contidas na nossa doutrina, e outra é a formulação com que são enunciadas, conservando-lhes, contudo, o mesmo sentido e o mesmo alcance. Será preciso atribuir muita importância a esta forma e, se necessário, insistir com paciência, na sua elaboração; e dever-se-á usar a maneira de apresentar as coisas que mais corresponda ao magistério, cujo caráter é prevalentemente pastoral (JOÃO XXIII, 2007, p. 671).

A Igreja é o sujeito responsável por ancorar a doutrina na história. A perspectiva pastoral do Concílio concretizava em termos teológicos e metodológicos esse exercício de transmissão da fé, agora em uma perspectiva que superava a cosmovisão fechada de uma doutrina fixa e congelada. O Vaticano II tinha essa tarefa primordial de discernir a fé em confronto com a realidade e vice versa.

Esta consciência histórica identifica-se, portanto, com o próprio processo de construção do Concílio, seja como método de trabalho, seja como método de reflexão. Desde a primeira sessão dissolvida com o intuito de dar aos padres maior conhecimento do que estava em curso, as discussões refeitas no Documento referente às Fontes (De fontibus), as reflexões sobre Igreja (De ecclesiae), sobre o diálogo com as demais religiões até as formulações teológicas e metodológicas oferecidas pela Gaudium et Spes, o processo 
conciliar revela uma ruptura permanente com esquemas teológicos essencialistas e adoção de esquemas marcados pela centralidade da história. Essa Constituição, filha inesperada do processo conciliar, constitui o retrato mais fiel do esforço de a Igreja acolher o tempo presente como grandeza teológica, de assumir o desafio do discernimento e de colocá-la em atitude de sensibilidade e solidariedade com a humanidade atual. Trata-se do Documento que oferece as bases teológicas e o método teológico fundamental do Concílio que consistiu em voltar às fontes a partir de referências hermenêuticas atuais e acolher positivamente a realidade presente.

A Constituição não somente pratica esse método fundamental em seu conjunto na maneira mais explícita e consciente, como fornece as regras que traduzem teológica e metodologicamente esse método na categoria sinais dos tempos que já havia sido utilizada e ensinada por João XXIII na Encíclica Pacem in terris (1963). Agora faz-se presente em várias passagens com as seguintes conotações: a) como exigência para descobrir os desígnios de Deus na história (GS, 4, 11); b) como leitura da realidade a partir da fé (GS 4, 11, 44; PO, 18); c) como missão da Igreja na compreensão, diálogo e serviço ao mundo (GS 4,11); d) como tarefa conjunta dos cristãos entre si (PO 9; DH 15), dos leigos com os presbíteros (PO 9) e dos cristãos com outros sujeitos (GS 11; DH 15); e) como sinal concreto expresso na solidariedade (AA 14) e na liberdade (DH 15); f) como conceito expresso na ação ecumênica entre os cristãos (UR 4); g) como diálogo com as várias linguagens e ciências na busca de aprofundamento da verdade revelada (GS 44); h) como fruto da leitura da Bíblia e que produz a docilidade ao Espírito (PO 18) (PASSOS, 2014, p. 253-257). Em termos teóricos pode-se dizer que a circularidade hermenêutica entre passado e presente, entre texto/tradição e contexto vai ser assumida sempre mais como perspectiva e método de pensar da Igreja e, de modo, regular nas suas assembleias colegiadas (GADAMER, 2002, p. 400-425).

O DP insere-se nesse horizonte metodológico herdado do Vaticano II. O método ver-julgar-agir estruturante do conjunto, a sensibilidade para com o contexto histórico, as ancoragens constantes do doutrinal na realidade presente e o foco constante na aplicabilidade pastoral permitem afirmar a prevalência de um método fundamental centrado na historicidade sobre os métodos dedutivos de matriz essencialista (KÜNG, 1999, p. 130-133). Além dessa "cultura eclesial", a Igreja da América Latina dispunha dos conteúdos e métodos já consolidados da teologia da libertação que ofereciam medidas precisas para o propósito de discernimento da realidade e compromisso com a situação concretas dos povos do continente por parte da Igreja. A III Conferência se deparava com a imponderabilidade do histórico na percepção da realidade e da fé, na busca de compreensão dos processos econômicos e políticos, na tomada de postura perante os desafios presentes e, por conseguinte, nas opões pelos modelos interpretativos das ciências e da teologia. 


\section{O método fundamental conciliar em Puebla}

O aggiornamento não foi somente uma postura que construiu o Concílio e traduziu-se em método utilizado pela assembleia, mas uma compreensão da própria missão da Igreja na história (em estado de relatividade institucional por ter sua origem e fim em Jesus Cristo, sinal de salvação, sinal do Reino, peregrina na história e servidoras da humanidade, de modo especial dos mais pobres) e de sua natureza (mistério de comunhão dos fieis inseridos em Jesus Cristo vivo, comunidade povo de Deus) e de sua organização (comunidade de membros com funções distintas, colegialidade episcopal, universal concretizado nas particularidades). Nessa compreensão eclesiológica, a Conferência de Puebla concretiza o mistério da Igreja e de sua missão na história, concretamente no continente latino-americano: a) Igreja universal vivenciada na particularidade latino-americana, Igreja povo de Deus, colegialidade eclesial, igreja servidora do povo e, portanto, de modo especial dos pobres. Puebla é a Igreja conciliar em permanente aggiornamento, em busca de si mesma na história da salvação em que se insere no momento concreto; b) Igreja que busca discernir os sinais dos tempos desencadeando uma circularidade entre passado e presente, fé e realidade: o presente é interpelação de Deus e convocação a ações concretas, estando a Igreja na busca de modos mais coerentes de pensar a si mesma em sua missão dentro da hora presente; c) Como esforço de leitura ética da realidade mediante o diálogo com as ciências aptas a esse discernimento em nome da verdade que brota da fé.

Portanto, se por um lado salta aos olhos uma dicotomia teológica que recorta o DP, por outro subjaz essa postura e método fundamental que não somente salva Puebla de um essencialismo doutrinal supra-histórico, mas também preserva a postura fundamental que confronta a fé com a realidade, o passado e o presente (KÜNG, 1999, p. 130-133). Essa consciência histórico-teológica filha do Vaticano II havia, de fato, encontrado um ponto saliente em Medellín. A II Conferência dera-se no rigor do método que confronta orgânica e criticamente fé e realidade com a técnica do ver-julgar-agir no antes, no durante e depois da assembleia. A Teologia da Libertação estivera ali presente com suas opções, posturas e métodos, ainda que se encontrasse na fase de fundação e, por essa razão, ainda sem os estigmas contraídos na década seguinte.

A consciência histórica constitui, desde o Vaticano II, uma espécie de subsolo da própria Igreja, mesmo quando se busca os meios mais teóricos (doutrinais, normativos etc.) de formular a fé ou que se proponha partir dos princípios para chegar-se à realidade, como rezava o método dedutivo escolástico. A era conciliar é a era da inserção da Igreja no tempo presente, onde examina permanentemente o sentido da fé e o sentido de si mesma (GS 4, 11 e 44). É esse pressuposto eclesial e metodológico que condiciona a 
leitura da realidade e a leitura da fé, instaurando um círculo hermenêutico entre passado e presente, entre os textos fundamentais da fé e o contexto presente (GADAMER, 2002, p. 443-453). Em Puebla a consciência histórica da Igreja rouba a cena das reflexões e decisões e expressa-se como coração que rege a circulação geral das orientações que vão sendo dispostas:

\section{$1^{\text {a: }}$ na sensibilidade para com a realidade}

A sensibilidade para com a humanidade concreta, especialmente com os pobres e sofredores, colocada como norma espiritual, eclesial e ética pelo Vaticano II (GS 1) ressoa em Puebla, sem ponderações; lança luz sobre a condição concreta dos povos do continente e coloca a Igreja em posição profética clara, sem as velhas negociações com as classes dominantes, ainda que a luta de classe fosse naquele contexto uma ambiguidade a ser cuidadosamente pensada pelos bispos. O grito dos pobres ouvidos em Medellín adquire maior nitidez e torna-se mais grave. Assim diz Puebla: “Do coração dos vários países que formam a AL está subindo ao céu um clamor cada vez mais impressionante" (87). Continua: "É o grito de um povo que sofre e que reclama justiça, liberdade e respeito aos direitos fundamentais dos homens e dos povos" (87). Afirmam sobre esse clamor: "Há pouco mais de dez anos, a Conferência de Medellín já apontava a constatação desse fato ao afirmar: 'Um clamor surdo brota de milhões de homens, pedindo a seus pastores uma libertação que não lhes chega de nenhuma parte' (Pobreza da Igreja 2)" (88). E que o "clamor pode ter parecido surdo naquela ocasião. Agora é claro, crescente, impetuoso e, nalguns casos, ameaçador" (89).

Essa conexão com Medellín nega a eficácia da pretendida hermenêutica revisora da segunda Conferência, ao menos no sentido de uma ruptura com a tradição que desde então havia consolidado; ela parece ter sido o suficiente para dar a Puebla o certificado do aggiornamento da Igreja na realidade latino-americana, exigir dela uma palavra de discernimento na linha dos sinais dos tempos, adotar o método ver-jugar-agir, pensar a realidade do ponto de vista teológico e colocar a Igreja na trincheira profética.

Do ponto de vista teológico, não parece ter sido a teologia clássica predominante na segunda parte (Julgar) que garantiu a fidelidade às verdades sobre Jesus Cristo, a Igreja e o homem, mas precisamente a sensibilidade para com aos clamores da realidade; os pobres salvaram Puebla da abstração teológica generalizada. Como não relembrar os itens referentes aos rostos sofredores de Cristo presente nos sofredores da América latina: “Esta situação de extrema pobreza generalizada adquire, na vida real, feições concretíssimas, nas quais deveríamos reconhecer as feições sofredoras de Cristo Senhor (que nos questiona, interpela)" (31). As feições sofredoras de oito sujeitos ali elencados revelam, de fato, uma síntese concreta entre 
o diagnóstico fiel da realidade ali retratada sem contornos e as fontes cristológicas da fé. As "feições concretíssimas" dos pobres e sofredores são as "feições sofredoras de Cristo". O DP exibe essa teologia libertadora como pórtico de entrada de seu conteúdo geral. Ao passar por esse pórtico todos ficam tomados da imagem mais viva da Igreja dos pobres e do compromisso evangélico para com os mesmos. Os reparos teológicos abundantes no Documento não se sobrepõem à vivacidade e apelo dessa entrada teológica, sociológica e pastoral desenhada com imagens concretas e interpeladoras.

\section{$2^{\mathrm{a}}$ : o método ver-julgar-agir}

O método geral do DP segue os passos clássicos de aplicação do método ver-julgar-agir (BRIGHENTI, 2015, p. 608-615), embora se possam verificar incoerências na aplicação do mesmo. Apesar da ausência de organicidade entre os três momentos, do que decorrem paralelismos teológicos - exemplo emblemático das cristologias presentes em 31-42 (modelo histórico-libertador) e 188-201 (modelo clássico) - é certo que o método manteve o vínculo fundamental da fé com a realidade e manteve a tradição já amplamente praticada pelos episcopados, pela teologia e pelas CEBs e pastorais populares pelo continente afora. O DP transmite novamente esse método às Igrejas, de forma que em cada localidade eclesial exercita-se esse modo de pensar a fé e planejar as ações concretas. Em nome de Puebla as Igrejas continuaram essa tradição e avançaram no compromisso com suas realidades concretas. A teologia tradicional predominante na segunda parte fica encaixada no esquema maior que a vincula à realidade, seja no ponto de partida, seja no ponto de chegada. O método trouxe para dentro do DP a realidade com seus apelos, de forma que a recepção do mesmo seguirá esse percurso concreto quando aplicado nos anos seguintes.

\section{$3^{\text {a: }}$ as ancoragens teológicas na teologia da libertação}

No interior dessa moldura metodológica geral é possível ainda verificar algumas ancoragens da fé com a realidade, na forma de conceitos e de apelos à ação na hora urgente do continente. É quando a teologia clássica de cunho dedutivo compõe com intuições teológicas da teologia da libertação historicamente situada. Ao que tudo indica, essas composições resultam de negociações e acréscimos que vão sendo inseridos no processo de redação com os textos oferecidos pelas comissões e como emendas acrescentadas durante os plenários. De fato, historicamente sabe-se por meios de testemunhas oculares da influência de teólogos latino-americanos que estiveram oficiosamente em Puebla, fora da assembleia, porem em sintonia direta com alguns bispos como assessore informais. O DP não pôde evitar a influência indireta desses teólogos. Algumas passagens revelam a presença das temáticas regulares da teologia da libertação. $\mathrm{Na}$ 
primeira parte, além da referida passagem cristológica (31-41), muitas outras podem ser resgatadas. Algumas passagens significativas: a) as causas estruturais da situação de pobreza dos povos são delineadas a partir da teoria da dependência, superando a visão desenvolvimentista frequentes em documentos eclesiais (63-70); b) o desafio da Igreja em ajudar o homem a passar de situações menos humanas a situações mais humanas, pois levar Deus até os homens implica construir uma sociedade fraterna (90); c) a consciência da missão evangelizadora leva a Igreja a assumir posturas proféticas por meio de pronunciamentos, criação de organismos em favor dos que sofrem, defesa dos direitos humanos, a opção pelos pobres (92); d) celebra o crescimento das CEBs desde Medellín, comunidades que se mostram como centros de evangelização e motores de libertação e desenvolvimento (96-98); e) a atividade ecumênica, expressão do diálogo, promove ações conjuntas de promoção humana (108); f) o anúncio de Evangelho deve desencadear a força do fermento de transformação (142).

Na mesma linha, na segunda parte de cunho doutrinal, podem-se surpreender ancoragens com a tradição de Medellín e da teologia latino-americana: a) Igreja enviada a evangelizar a todos, de modo especial aos mais pobres e esquecidos (164); b) introduzindo as três verdades afirma Jesus Cristo como libertador, a Igreja como servidora da humanidade e o Homem como digno com quem a Igreja tem um compromisso libertador (166-169); c) a denominação da queda original como opção do homem pelos ídolos falsos (185); d) a condição de pecado do ser humano concretiza-se em seu extremo limite na situação da América Latina (186); e) a encarnação do Verbo de Deus eleva o ser humano a uma dignidade altíssima e irrompe em sua peregrinação rumo à liberdade e à fraternidade (188); f) a força do Espírito Santo anuncia a libertação integral de todos e de cada pessoa do povo de Deus (189); g) Jesus de Nazaré ama a todos, mas privilegia os pequenos, os fracos e os pobres (192); h) Jesus ressuscitado está presente entre os que se reúnem em seu nome e quis identificar-se com os mais fracos e os pobres (196); i) o Espírito Santo assumiu o que havia de bom nas culturas pré-colombianas (201); j) a Igreja está a serviço do Reino de Deus, é mistério de comunhão do povo de Deus (226 e 232); 1) a Igreja é comunidade que supera o individualismo (235); m) o povo de Deus é servidor da comunhão e a Igreja é uma escola de sujeitos históricos (270 e 274); n) todo homem e mulher são dignos por si mesmo e invioláveis (317); o) são condenados todo menosprezo, diminuição ou injúrias às pessoas em seus direitos inalienáveis (318).

A terceira parte dedicada ao momento do Agir estrutura-se a partir de uma eclesiologia povo de Deus, mistério e compromisso de comunhão e participação de todos os membros. Aí fica evidente um modelo eclesial 
que supera a visão e a prática de uma Igreja centrada e identificada com sua hierarquia e se entende primariamente como comunidade de iguais em Jesus Cristo e destinada a servir a humanidade, de modo especial os mais pobres. O esforço de integração da hierarquia com os leigos, as CEBs e os movimentos perpassa os quatro capítulos, afirmando a mesma missão de testemunho e serviço junto ao povo do continente. $\mathrm{O}$ agir apresenta um rosto eclesial conhecido das comunidades naquela ocasião, bem como um ideal que era afirmado como natureza e missão da Igreja na história nas diretrizes pastorais, na prática das Igrejas e nos discursos que referenciavam a práxis eclesial. A terceira parte fala por si mesma, como delineamento de opções concretas da Igreja na busca de fidelidade ao momento urgente do continente. Ainda que na ordem textual - e até mesmo metodológica - seja a última, constitui na verdade o ponto de partida e a perspectiva de todo o documento, senão de toda a assembleia. Quando se adota uma perspectiva pastoral em uma reflexão e decisão eclesial, a historicidade emerge como dado fundante e determinante de todo o conjunto, mesmo havendo uma intenção de revisão de erros teológicos presentes na Conferência e no próprio texto final. A esse respeito comenta com lucidez Luiz Alberto G. Souza:

[...] a construção de um texto pastoral não se faz por via negativa, mas principalmente através da descrição de alguns fatos relevantes e iluminadores [...]. Nisto radica a diferença com documentos doutrinários, que podem ficar no plano dos princípios gerais e nem sempre descem ao real. No momento em que Puebla quis ser um encontro pastoral, já um certo diagnóstico se impôs e alguns bispos, ligados a um trabalho de renovação pastoral, tiveram, automaticamente, uma presença bem mais forte $(1979$, p. 68).

A consciência da história foi, de fato, o pressuposto hermenêutico que determinou a leitura da tradição teológica e das referências doutrinais oficiais, estabelecendo um círculo hermenêutico de fundo de toda a reflexão, de forma que o presente leu o passado com suas interrogações e clamores (GADAMER, 2002, p. 400ss). O DP insere-se na história das Igrejas do continente, naquele contexto dramático que clamava por mudanças urgentes; expressa um momento das opções dessas mesmas Igrejas que se sentiram amparadas pelas orientações da II Conferência de Medellín e oferece orientações para o discernimento e a inserção da Igreja nos contextos em que houver pobres e oprimidos que clamam por libertação. A consciência da presença de Deus na história humana concreta e a busca de referências teológicas que possibilitassem o discernimento dessa presença e a missão coerente da Igreja insere Puebla na historicidade de Deus, do ser humano e da Igreja, superando qualquer abstração teológica a respeito dessas verdades. Essa posição fundamental ressoa solenemente na proclamação dos bispos na Mensagem final aos povos da América Latina: Deus está presente e vivo, por meio de Jesus Cristo libertador, no coração da América Latina. 


\section{Considerações finais}

A luta estabelecida na longa temporalidade moderna entre as visões essencialista e histórica, reproduzida tardiamente na Igreja católica, primeiro na teologia, em seguida no magistério papal, teve seu ponto de envergadura no Vaticano II e seu acerto de contas na Conferência de Puebla; momento estratégico de recuperar uma visão segura e estável da verdade sobre Deus, o ser humano e a Igreja. A luta hermenêutica pelos significados autênticos do aggiornamento conciliar acolhido e praticado na América Latina buscou seus modos de operação eficientes no processo - antes, durante e depois - que constrói o evento Puebla. O DP se insere nessa perspectiva de tensão eclesial e de opções teológicas. Contudo, se a teologia clássica postada como a teologia oficial e legítima capaz de corrigir os erros da teologia e da Igreja latino-americanas, exibe sua força formal e doutrinal na seção dois do documento (Julgar), a teologia da libertação (sem jamais ser assumida com essa nomenclatura, proscrita de um texto daquela natureza eclesial e naquele momento) ofereceu as ancoragens difusas no conjunto do documento, dando às orientações os vínculos desejados entre a fé e a realidade.

A consciência da centralidade da história para compreender o ser humano em suas condições reais e, ao mesmo tempo, a revelação histórico-salvífica desencadeia uma dinâmica que resulta: a) numa compreensão una de história (a mesma história humana e da salvação), numa perspectiva escatológica (história atual e Reino de Deus); b) na postura de discernimento permanente do tempo presente (os sinais dos tempos com suas decorrências metodológicas); c) na postura de diálogo com a sociedade e cultura contemporânea (diálogo com as diferenças) e d) na solidariedade com as angústias e sofrimentos (sobretudo dos pobres). Essa dinâmica exige a articulação teórica da fé com a realidade, a inserção da Igreja nas realidades locais e a interação mística entre fé e vida. A Conferência de Puebla esteve situada nesse a priori teológico e nesse clima eclesial e, a partir desses, fez-se em sua totalidade. Sua intencionalidade pastoral primeira ofereceu o mapa fundamental das opções e a estrutura subjacente das reflexões e definições que compuseram o conjunto do documento final. A consciência histórica triunfou sobre a percepção e método dedutivos de viés essencialista que separa a doutrina fixa das urgências da vida concreta.

Se, para os vigilantes da ortodoxia, a reta doutrina, expressa nos termos do modelo teológico clássico, haveria de salvar a Igreja da América Latina dos desvios referentes ao aggiornamento conciliar aprofundado e amplificado em Medellín, para uma Puebla real, os pressupostos de uma fé e de uma teologia ancoradas na história garantiram sua linhagem direta com Medellín e Vaticano II. Os clamores dos pobres foram clamores de Deus. 


\section{Siglas}

AA - Apostolicam Actuositatem

CEB - Comunidade Eclesial de Base

CELAM - Conferência geral do Episcopado Latino-Americano

DH - Dignatatis Humanae

DP - Documento de Puebla

GS - Gaudium et Spes

PO - Presbiterarum Ordinis

UR - Unitatis Redintegratio

\section{Referências}

ABAGNANO, N. Dicionário de filosofia. São Paulo: Martins Fontes, 2007.

ALMEIDA, A. J. Aggiornamento. In: PASSOS, J. D.; SANCHEZ, W. L. (Orgs.). Dicionário do Concílio Vaticano II. São Paulo: Paulus/Paulinas, 2015a. p. 8-9.

Ação católica. In: PASSOS, J. D.; SANCHEZ, W. L. (Orgs.). Dicionário do Concílio Vaticano II. São Paulo: Paulus/Paulinas, 2015b. p. 2-5.

ÁVILA, F. B. de. O pensamento social cristão antes de Marx. Rio de Janeiro: Livraria José Olímpio, 1972.

BRIGHENTI, A. Método ver-julgar-agir. In: PASSOS, J. D.; SANCHEZ, W. L. (Orgs.). Dicionário do Concílio Vaticano II. São Paulo: Paulus/Paulinas, 2015. p. 608-615.

CASALDÁLIGA, P. Visão de Igreja a partir da periferia. Revista Eclesiástica Brasileira, Petrópolis, v. 38, n. 152, p. 579-605, 1978.

CASSIRER, E. A filosofia do iluminismo. Campinas: Unicamp, 1992.

CASTELlS, M. O poder da identidade. São Paulo: Paz e Terra, 2001.

COMBLIN, J. La conferencia episcopal de Puebla. In: SELADOC. Panorama de la teología latino-americana. Puebla. Salamanca: Sígueme, 1981. p. 91-104.

DUSSEL, E. La iglesia latinoamericana de Medellín a Puebla. In: SELADOC. Panorama de la teología latino-americana: Puebla. Salamanca: Sígueme, 1981. p. 13-61.

Loyola, 1983. t. 3.

. De Medellín a Puebla: uma década de sangue e esperança. São Paulo:

FAGGIOLI, M. Vaticano II: a luta pelo sentido. São Paulo: Paulinas, 2013.

GADAMER, H.-G. Verdade e método: traços fundamentais de uma hermenêutica filosófica. Petrópolis: Vozes, 2002.

GIBELLINI, R. A teologia do século XX. São Paulo: Loyola, 1998.

III CONFERÊNCIA GERAL DO EPISCOPADO LATINO-AMERICANO. Conclusões de Puebla. São Paulo: Loyola, 1982. 
JOÃO XXIII, Papa. Tutti i principali documenti: latino-italiano. Città del Vaticano, Libreria Editrice Vaticana, 2007.

KÜNG, H. Teologia a caminho: fundamentação para o diálogo ecumênico. São Paulo: Paulinas, 1999.

LIBÂNIO, J. B. Volta a grande disciplina. São Paulo: Loyola, 1984.

PASSOS, J. Décio. Concílio Vaticano II: reflexões sobre um carisma em curso. São Paulo: Paulus, 2014.

SOUZA, L. A. G. Documentos de Puebla: diagnóstico a partir dos pobres. Revista Eclesiástica Brasileira, Petrópolis, v. 39, n. 153, p. 64 - 87, 1979.

SOUZA, N. de; SBARDELOTTI, E. (Orgs.). Puebla: Igreja na América Latina e no Caribe. Petrópolis: Vozes, 2019.

THEOBALD, C. A recepção do Concílio Vaticano II: acesso à fonte. São Leopoldo: Unisinos, 2015. v. I.

TRUjILlO, A. L. Opções e interpretações à luz de Puebla. São Paulo: Loyola, 1982.

VAZ, H. C. de L. Ontologia e história; São Paulo: Loyola, 2001.

VILANOVA, E. Historia de la teología cristiana. Barcelona: Herder, 1989. t. II.

ZEPEDA, J. de J. L. A luta pelo sentido do Vaticano II em seu processo de recepção nas Conferências Gerais. In: BRIGHENTI, A.; PASSOS, J. D. Compêndio das Conferências dos bispos da América Latina e Caribe. São Paulo: Paulus/Paulinas, 2018. p. 119-131.

Artigo submetido em 13.06.2019 e aprovado em 16.08.2019.

João Décio Passos é doutor em Ciências Sociais pela Pontifícia Universidade Católica de São Paulo - PUC-SP (2001). Professor Associado do Departamento de Ciência da Religião da Pontifícia Universidade Católica de São Paulo -PUC-SP. Orcid.org/0000-0003-4390-0423. E-mail: jdpassos@pucsp.br

Endereço: Rua Wanderley, 504/181

Perdizes

05011-001 São Paulo - SP 